August 2011

\title{
The African Standby Force, Genocide, and International Relations Theory
}

Stephen Burgess

Follow this and additional works at: https://digitalcommons.usf.edu/gsp

\section{Recommended Citation}

Burgess, Stephen (2011) "The African Standby Force, Genocide, and International Relations Theory," Genocide Studies and Prevention: An International Journal: Vol. 6: Iss. 2: Article 4.

Available at: https://digitalcommons.usf.edu/gsp/vol6/iss2/4

This Articles is brought to you for free and open access by the Open Access Journals at Digital Commons @ University of South Florida. It has been accepted for inclusion in Genocide Studies and Prevention: An International Journal by an authorized editor of Digital Commons @ University of South Florida. For more information, please contact digitalcommons@usf.edu. 


\title{
The African Standby Force, Genocide, and International Relations Theory
}

\author{
Stephen Burgess 1 \\ US Air War College
}

In launching the African Standby Force (ASF), African leaders over-promised to stop genocide, given their lack of political will, the weak capacity of their states, and the weak military capability of the Force's subregional brigades. The explanation lies in a combination of South African idealism and determination to exert continental leadership and the desire of African leaders to sustain or increase aid to their under-resourced militaries. South Africa does not have the power or resources necessary to supply sufficient public goods to make the ASF fully functional and capable of fulfilling all tasks. African leaders promised to stop genocide with the calculation that no one with sanctioning power would challenge them. Burden shifting by the United States and other major powers was such that African leaders expected to be rewarded with increased aid flows. A combination of African nationalism and aid dependence trumped a highly needed international public good - the political will and military capability to stop genocide.

Key words: African Standby Force, genocide, intervention, idealism, burden shifting, political will, aid dependence, capacity and capability

In international politics, it is common for the leaders of states and organizations to make promises and commitments to supply international security and then not deliver on such promises. In contrast, domestic "political entrepreneurs" are usually punished, particularly in democracies, if they do not at least partially fulfill promises to deliver national security and other public goods. The anarchical nature of international politics means that there is little incentive to prevent leaders from making promises to supply international security and other public goods that they know might not be fulfilled. Furthermore, the leaders of member states belonging to an international organization are able to "scapegoat" the body; thereby, leaders can minimize responsibility for over-promising and failing to fulfill those promises. According to realist theory, the collective action problem and the tendency of weaker states to "free ride" can only be overcome by a hegemonic power which is willing to supply the lion's share of the goods. ${ }^{2}$ According to institutionalist theory, a hegemonic power can lead in establishing a "regime" to which member states contribute a share, thus mitigating free ridership. ${ }^{3}$ In international security, the two best-known regimes revolve around the North Atlantic Treaty Organization (NATO) and collective defense and the United Nations (UN) and peacekeeping and peacebuilding. However, in a crisis situation, such as the 1994 Rwandan and 2004 Darfur genocides, regimes and their rules are not sufficient to compel UN or NATO member states to act and the hegemonic power-the United States-to lead in order to supply the necessary public goods.

There are various reasons why leaders over-promise or make unattainable promises to supply international security and other public goods, including a desire for prestige as well as earnest efforts to solve difficult international problems. Some

Stephen Burgess, "The African Standby Force, Genocide, and International Relations Theory." Genocide Studies and Prevention 6, 2 (August 2011): 121-133. (C) 2011 Genocide Studies and Prevention. doi:10.3138/gsp.6.2.121 
leaders make promises without realizing that there may be a lack of political will and capability to respond, while others consciously lie. ${ }^{4}$ Middle powers and smaller states wish to demonstrate their usefulness in the international order, and poorer states strive to receive aid. Leaders of organizations such as the UN and African Union (AU) over-promise because of a desire to prove the legitimacy of their organizations and its worthiness to receive financial support or because of pressures from member states to respond to supply security. ${ }^{5}$

The hegemonic power and other strong states tend to cooperate with weak states and organizations in order to "burden shift" and provide aid and/or side payments, thereby compounding the problem and adding to the shortfall in international security caused by over-promising. This tendency is explained by the difficulty and costliness of supplying security in genocidal situations combined with the lack of interest and low salience of more powerful states. As an alternative, major powers persuade and pressure smaller and weaker states and international organizations to assume burdens that they lack the capability and will to manage. The gap between weak states' overpromising and powerful states' burden shifting compounds the collective action problem and causes failures in international security, including the failure to intervene to stop genocide.

One of the thorniest international security issues is preventing or stopping genocide. Most states have ratified the 1948 Genocide Convention, which obliges them to "prevent and punish genocide." 6 However, states have not acted to prevent or stop genocide, especially in Rwanda (1994), Darfur (2003-2004), and Bosnia (1992-1995). A principal limiting factor has been a lack of political will on the part of state leaders, including the leaders of major powers, to send forces to intervene in the internal affairs of sovereign states. A secondary factor has been a lack of military capacity on the part of states in the affected region that might have an interest in preventing genocide and keeping it from spilling over their borders.

A relevant case of over-promising international security is that of African leaders who approved the formation of the African Standby Force (ASF) and signed off on the promise that the ASF would be prepared by 2010 to intervene to stop genocide. In 2003, the AU Peace and Security Commission and the African Chiefs of Defense Staff (ACDS) devised the ASF and outlined six "typical conflict scenarios" in the ASF's policy framework. By 2010 the ASF would be able to meet the challenges presented by six scenarios laid out by the ACDS. The most challenging would be Scenario 6, the deployment of a robust military presence in 14 days to stop genocide:

1.6 A number of typical conflict scenarios, outlined below were used to develop the proposals in this document:

f. Scenario 6. AU intervention-e.g. genocide situations where international community does not act promptly.

The document specifies the capabilities that would be required by the ASF to respond to "genocide situations":

2.8 The speed with which forces will be required to deploy has particular implications for standby force structures and arrangements. Linked to this is the type of conflict into which they will deploy. Given the fluid and uncertain nature of conflict, particularly in Africa, coherence on deployment will be critical. This demands that units and HQ staff will have trained together prior to deployment. Significant implications of varying readiness levels are:

At 14 days readiness collective training involving field exercises with all units is essential prior to activation. At this level of readiness there is also a clear requirement for a standing fully staffed brigade $\mathrm{HQ}$ and $\mathrm{HQ}$ support. There is also a require- 
ment for an established and fully stocked logistics system capable of sustaining the entire brigade. Apart from large military alliances such as NATO, individual Member States may be best placed to provide this capability.

The document stipulates the need for rapid reaction capability to respond in two weeks' time:

2.9 Bearing this in mind, the Meeting recommends the following long-term deployment targets for the ASF (all timings are from an AU mandate resolution):

c. Due to the nature of situations demanding intervention operations, Scenario 6 , it will be important the AU can deploy a robust military force in 14 days. ${ }^{7}$

At the July 2004 summit in Addis Ababa, Ethiopia, the AU heads of state approved the proposal for the ASF, including the policy framework and intention to respond to Scenario 6, with 2010 as the target date for full implementation. However, 2010 has come and gone, and African countries and the ASF have not come any closer to being able to meet the challenge of Scenario 6. African leaders have little or no will to intervene in the sovereign affairs of African states. African states do not have the capacity and the ASF does not have the military capability to respond to Scenario 6. This is clear if African military capabilities, and especially those of the ASF subregional brigades, are examined in relation to the task of intervening to stop genocide. It appears that, by approving the ASF, AU heads of state and ACDS leaders were over-promising, though probably not lying. The reasons for over-promising vary from African heads of state and defense forces that were willing to go along with the ASF proposal because it increased the likelihood of receiving aid to South African President Thabo Mbeki, who had a long-term political and security vision for Africa, and to South African security experts, who helped operationalize Mbeki's vision. Mbeki and other South African leaders and officials promoted the goals of an "African Renaissance" and "African solutions for African problems," and African nationalist ideology is the basis for several grand schemes, including the ASF. 8

Given the lack of accountability in international politics and the tendency to over-promise, an additional question is how far are leaders, states, and organizations willing to push their promises. Is there anything that constrains them from making wildly unrealistic promises and lying? It would seem that there is a certain point at which incredulity arises about the promises of weaker states and organizations and at which stronger powers must step in to provide international security and other public goods or turn to the United Nations (UN) to do so, which is what happened after the AU failed to stop genocide in Darfur from 2004 to 2007 and was superseded by the UN. ${ }^{9}$

\section{Genocide and What It Takes to Stop It}

As defined by the Genocide Convention,

genocide means any of the following acts committed with intent to destroy, in whole or in part, a national, ethnical, racial or religious group, as such:

(a) Killing members of the group;

(b) Causing serious bodily or mental harm to members of the group;

(c) Deliberately inflicting on the group conditions of life calculated to bring about its physical destruction in whole or in part;

(d) Imposing measures intended to prevent births within the group;

(e) Forcibly transferring children of the group to another group. ${ }^{10}$ 
The difficulty of proving "intent to destroy" has led to disagreements about whether or not the mass killings and displacement of people in Bosnia, Kosovo, and Darfur constituted genocide or the more euphemistic "ethnic cleansing." Subsequently, former President Slobodan Milošević of Serbia and President Omar el-Bashir of Sudan were indicted by international courts on charges of genocide.

Only in the case of Kosovo in 1999 was NATO able to stop ethnic cleansing, but only after 850,000 people had been expelled from their homes by Serbian forces. A key factor was the political will of President Bill Clinton, Secretary of State Madeline Albright, and other NATO leaders to prevent the 1992 Bosnian ethnic cleansing that had dragged on for three years from repeating in Kosovo. However, NATO leaders were reluctant to risk any casualties and announced that no ground forces would be used. Fortunately, the United States and other NATO members were able to use air force to coerce Serbia to stop ethnic cleansing and allow Kosovar Albanians to return to their homes. The Bosnia case demonstrates that weak political will and undermobilized capability lead to failure, while Kosovo shows that a combination of strong political will and technologically advanced capacity and capability can stop genocide. African leaders lack the will, capacity, and capability to do the same.

\section{The Lack of Political Will to Stop Genocide in Africa}

There is a large body of evidence to prove that there is a lack of political will on the part of African state and organization leaders to stop genocide. ${ }^{11}$ Since the formation of the Organization of African Unity (OAU) in 1963, African leaders have agreed on the importance of sovereignty and non-interference in the internal affairs of member states. ${ }^{12}$ When genocide was committed in Burundi in 1972 and 1993 and in Rwanda in 1994, African states and organizations did nothing to intervene. ${ }^{13}$ When Tanzania intervened in Uganda in 1979 to overthrow the murderous Idi Amin regime, widespread protests were raised by OAU member states against the violation of sovereignty. Furthermore, Tanzania only invaded after Amin had ordered his forces to seize a section of Tanzanian territory.

With the foundation of the AU in 2002, it was hoped that the new organization, with South African leadership, would be more assertive in providing greater Africawide security and perhaps even be able to prevent or stop genocide. However, the AU did not respond in 2003 and 2004 to genocide in Darfur as a result of a lack of political will and a shortfall of African military forces. South African leadership in the AU did not make a difference. The Sudanese military dictatorship was determined to continue its scorched-earth campaign and resisted all efforts to place an effective international force in Darfur. Only after hundreds of thousands were killed and millions displaced as well as considerable international pressure did the Sudanese government agree to the deployment of an AU peacekeeping force. This force proved inadequate, and the Sudanese military and militias continued to destroy villages and murder, rape, and displace people.

The lack of political will to punish genocide has been recently manifested in many African leaders' refusal to accept the 2009 indictment of President Omar ElBashir by the International Criminal Court (ICC) for ordering massive crimes against humanity, including genocide, in Darfur. A 2009 AU heads of state summit, in fact, called on the UN Security Council to delay the ICC indictment from coming into effect. ${ }^{14}$ Political resistance to genocide prevention has also been evidenced by the controversy over the Responsibility to Protect (R2P) principle, which stipulates that governments must commit to protect civilians or call on international assistance if unable to do so. Many African states have resisted signing up for the principle in 
the UN because they fear external intervention in their own internal affairs. Efforts to separate the R2P principle from the type of humanitarian intervention that would be needed to stop genocide have met with limited success. ${ }^{15}$

\section{The Lack of Capacity and Capability to Stop Genocide}

On paper and in practice, the African Standby Force (ASF) and African militaries lack the enforcement capabilities needed to intervene, stop genocide, and defeat spoilers. At present, the ASF mainly consists of a dozen or so infantry battalions. ${ }^{16}$ The ASF possesses little of the armor, airborne and air power capabilities that an intervention to stop genocide requires. ${ }^{17}$ Furthermore, a multinational force will be unable to achieve the unity of effort to deploy and stop genocide.

More specifically, the full implementation of the ASF subregional commands entails the development of a number of other capabilities, including airlift, sealift, and ground transportation to dispatch the rapid deployment units and main ASF brigades and their equipment to conflict zones and re-supply them. Considerable logistics and maintenance capabilities are needed to sustain the brigades on a multinational basis. Interoperability, including interoperable communications, is required for the brigades to achieve unity of effort in the field. Intelligence capabilities are needed to allow the brigades to operate effectively in their areas of responsibility. ${ }^{18}$

Full ASF implementation means that the full cost of it must be borne by each of the subregional commands and their member states, which is still a distant dream. Effective command and control by subregional organizations and force commanders over the brigades require combined training exercises as well as sound communication with subregional headquarters and the AU Peace and Security Commission. The subregional brigades are charged with developing the ability to deploy field level headquarters that take orders from the AU mission planning cell in Addis Ababa. All of these capabilities are presently lacking to one degree or another. The ASF and the subregional brigades did not achieve full implementation by the December 2010 deadline and the ASF is unable to intervene in "genocide situations where international community does not act promptly."

Some subregional brigades will be more effective in practice than others. The Economic Community of West African States (ECOWAS) and the West African Brigade (ECOBRIG) appear to be well organized, led, and planned, but they have not proven their effectiveness in the field and do not have the capability to respond rapidly to stop genocide. The Southern African Development Community (SADC) and the Southern African brigade (SADCBRIG) with South African leadership will probably be more effective if their commitment level continues to increase. The South African National Defense Force may still possess the capability of leading a response to genocide even though it has deteriorated over the last decade. The East African brigade (EASBRIG) has the advantage of the highly capable and willing Rwandan military, which is providing leadership in the building of a rapid reaction force and could lead a response to genocide. The EASBRIG suffers from a lack of command and control as a result of Ethiopia's detachment from the countries of the East African Community.

The countries of the Economic Community of Central African States (ECCAS) have relied on France for leadership, organization, and logistics, especially in peacekeeping operations in the Central African Republic (CAR); thus far, the Central African brigade does not have the capability to respond to genocide. The North African brigade is presently organizing under Egyptian, Libyan, and Algerian leadership, but unity of effort is proving difficult. 
The hardest part-full and effective ASF operationalization with the rapid reaction capability that can stop genocide-remains to be developed. Well into the future, there will be chronically unstable states, such as Somalia, Sudan (North and South), Central African Republic, Chad, and the Democratic Republic of the Congo (DRC), which will continue to face military challenges from rogue states, insurgents, warlords, and militias that the ASF will not be able to confront and defeat. Even in the long run, it is not likely that the ASF subregional commands will be a force for rapid response in "genocide situations." Africa's poverty and lack of state capacity are major impediments that prevent the ASF subregional commands from being fully developed.

In practice, the operational cases of African peacekeepers in conflict zones, including Darfur and Somalia, have not been encouraging. The African Union Mission in Sudan (AMIS) was undersubscribed with only a few thousand peacekeepers without helicopters or other mobility, which meant that the mission was largely ineffectual for four years. ${ }^{19}$ In 2008, the UN established a hybrid mission that expanded the peacekeeping force from 5,000 troops to 19,500 troops and 6,500 police. This hybrid mission proved more effective, but conflict and human rights abuses continued. The African Union Mission in Somalia (AMSIOM) has been even weaker. Less than half of the requested 8,000 troops were deployed and Nigeria, Ghana, and Malawi refused to fulfill pledges to deploy battalions. As a result, AMISOM peacekeepers have been confined to Mogadishu and have become targets for Al Shabaab Islamist militia fighters.

Other relevant examples include Côte d'Ivoire in 2002, where ECOWAS forces proved inadequate to stabilize the situation in the wake of civil war and French forces had to enforce a cease-fire. In Liberia in 2003, Nigeria and other ECOWAS states intervened in the wake of a cease-fire but needed the threat of force from the 26th US Marine Expeditionary Unit to ensure stability. ${ }^{20}$ A month later, ECOWAS handed over authority to the UN Peacekeeping Mission in Liberia (UNMIL), which had the capacity to build up the peacekeeping force and sustain it.

The fundamental problem for African militaries and the ASF is a lack of assets, resources, and sustainability. Future economic growth may provide some African states with greater resources for possible use in building the ASF and subregional brigades. However, this will still leave the ASF and its brigades deficient in regard to the type of resources to fully develop, achieve self-sufficiency, and be successful in addressing Scenario 6. More specifically, it is difficult for poor countries lacking trained personnel to develop airlift, logistics, and maintenance. Most small militaries cannot afford to maintain standby units and keep them in a state of readiness for extended periods. There is the possibility that donor fatigue will arise and that ASF structures and functions will atrophy. ${ }^{21}$

Political will and force projection capabilities are the missing ingredients that can only be provided by the United States, Britain, France, and a few other countries. $^{22}$ Their leadership in NATO intervention in Bosnia in 1995 and Kosovo in 1999 established a security regime against genocide and ethnic cleansing in most of Europe outside of Russia's sphere of influence. ${ }^{23}$ In Africa, there are no great powers that can provide the political will and military capability to counter genocide.

\section{Why African Leaders Promised to Stop Genocide}

The motivation to promise to stop genocide came in the wake of criticism of the OAU and African leaders who did nothing as the Rwandan genocide unfolded over 100 days. In particular, Nelson Mandela and Thabo Mbeki came to power in South 
Africa on 10 May 1994 as genocide was occurring and regretted their inability to act. In response, both Mandela and Mbeki strove to find a way to stop mass killings in Burundi. In 2000, Mandela assumed control of negotiations to end civil war in Burundi and develop a power-sharing arrangement, and his successor, President Thabo Mbeki, committed South African troops to protect Burundian political leaders and then act as the vanguard of the AU Peacekeeping Mission in Burundi (AMIB). The South African determination to stop mass killings and genocide influenced its leadership role in the formation of the ASF and the commitment to stop genocide. ${ }^{24}$

Mbeki promoted the African Renaissance concept with the vision of ending violence, elitism, corruption, and poverty in Africa and creating the basis for economic progress. ${ }^{25}$ Mbeki's leadership, South African diplomacy, and the cooperation of a number of prominent African leaders played a major role in the African Renaissance campaign and the 2002 founding of the African Union. Under the AU Charter, the AU Peace and Security Council was given greater power to authorize intervention in conflicts and to monitor human rights situations in member states. On paper, sovereignty would no longer be as powerful as it had been under the OAU Charter. In a similar vein, South African leadership spawned the New Partnership for Africa's Development (NEPAD) and the African Peer Review Mechanism (APRM), to which African states would submit to review their security and governance situations. The African Renaissance, NEPAD, and APRM were manifestations of African nationalism as well as South African liberal internationalist repackaging. One of the aims was to attract more aid and investment from the West. The slogan, "African solutions to African problems," became prominent among African leaders at this time. ${ }^{26}$

South African idealism, manifested in the African Renaissance concept, was reflected in the establishment of the ASF. ${ }^{27}$ After the founding of the AU Peace and Security Council, and Peace and Security Commission, South African leadership played a major role in influencing the African Chiefs of Defense Staff (ACDS) to adopt the ASF policy framework, including Scenario 6-AU intervention in genocide situations. In July 2004, African leaders signed off on the ASF policy framework with little comment on Scenario 6. For them, it was more important to launch the ASF with the prospect of attracting Western aid. Therefore, over-promising to stop genocide was largely a product of South African ambition and hegemony as well as acquiescence by African leaders to seek an increasing flow of aid for their militaries. ${ }^{28}$

\section{Why the United States and Other Major Powers Burden Shifted}

The United States, as well as Britain, France, and other major powers, allowed the AU and ACDS's commitment to use the ASF to intervene to stop genocide to go unchallenged, which fits into the pattern of powerful states' burden shifting when intervention is not in their national interest. Clearly, intervention to stop genocide in Africa has not been and is not in their national interest. ${ }^{29}$ Ever since the 1993 killing of 18 US soldiers in a peace enforcement mission in Somalia, the United States sought to avoid intervention in Africa at all costs and shift the security burden to African states. After the United States failed to respond to the Rwandan genocide, the Clinton administration apologized for failing to act but still sought to shift the burden of responding to genocide to African states. In 1996 the United States proposed an African Crisis Response Force which, developed with US and European funding and training, would create a standby force that could, among other things, intervene to stop genocide. After African leaders rejected the concept as too paternalistic, the United States launched the African Crisis Response Initiative (1997-2001) 
to train African peacekeepers and followed it with the Africa Contingency Training and Assistance (ACOTA) program from 2002 onward. In 2004, the United States joined European states in the Global Peace Operations Initiative to cooperate in training 75,000 African peacekeepers. The vast majority of training by the United States, France, Britain, and other countries prepared peacekeepers to serve only once a cease-fire had been secured. Very little of the training was suitable to prepare for intervention in genocide situations, which is what had supposedly motivated the United States and other countries to initiate the training in the first place.

In 2007, the United States announced the formation of the US Africa Command (AFRICOM), which became fully operational in October 2008. The mission of AFRICOM is to partner with African militaries with the aim of making them more effective operationally. AFRICOM accomplishes its mission primarily through joint exercises with African militaries. AFRICOM has been particularly interested in working with the ASF and moving it toward operational effectiveness. AFRICOM has done little or nothing to prepare to intervene in order to stop genocide. ${ }^{30}$

\section{Conclusion}

Given their lack of political will, the weak capacity of their states, and the weak military capability of the ASF subregional brigades, African political and military leaders have over-promised to stop genocide in agreeing to respond to ASF Scenario 6. The explanation for this behavior lies in a combination of South African idealism, exemplified by the African Renaissance concept, and determination to exert continental leadership and African leaders' desire to sustain or increase aid to their under-resourced militaries. South African behavior fits the mold of middle powers, which try to make an impact on the international system through multilateral initiatives that appear overly idealistic. ${ }^{31}$ South Africa, as the aspiring hegemon in Africa, does not have the power or resources to supply sufficient public goods to make the ASF fully functional and capable of fulfilling all tasks. ${ }^{32}$

The conduct of African leaders can be explained by their countries' poverty and their desire to obtain resources to sustain their militaries. ${ }^{33}$ African leaders promised to stop genocide with the calculation that no one with sanctioning power would challenge them. Indeed, as African leaders had anticipated, the United States and other major powers responded with burden-shifting behavior and rewarded the ASF proposal with increased aid flows. Also, Scenario 6 was just a part of the ASF policy framework and did not attract the attention of the human rights NGO community or that of the major powers. Thus, a curious combination of African nationalism and aid dependence trumped a highly needed international public good-the political will and military capability to stop genocide. In several regions of the world, weak states and organizations exhibit similarly contradictory behavior.

In regard to the limits of over-promising, the ASF policy framework did not contain the promise that African standby brigades would always be able to stop genocide on their own. Indeed, the ASF policy framework stated that it would intervene in "genocide situations where international community does not act promptly." However, given the unwillingness of the United States and other major powers to "act promptly" and intervene, the promise was actually grander than it may have seemed. In regard to over-promising that the ASF would be fully operational and capable of acting in all six scenarios by the end of 2010 , this was done with the aim of injecting a sense of urgency into the development of the ASF. However, the failure to come close to meeting the 2010 deadline calls into question the credibility of African leaders and even concepts such as the "African Renaissance" and "African 
solutions for African problems." 34 The ASF goals to be fully operational by 2010 and to stop genocide reflect a tendency to set unattainable goals. This is evident in the 2015 target date for achieving the Millennium Development Goals for Africa, an aim that will likely not be met. It is also apparent in the unrealistic goals of the New Partnership for African Development (NEPAD), especially the African Peer Review Mechanism (APRM), which promises that African states will make major changes to their governance in response to peer review and the desire to increase foreign investment. Challenging timetables may prod African governments to develop their militaries, but they also lead to unrealistic expectations and suboptimal performance, such as the AU missions in Darfur and Somalia.

The ASF concept will not be fully implemented in the foreseeable future because African states are too poor and lack the capacity necessary for implementation. In spite of this reality, African leaders, organizations, and advisers have set up a scheme that promises to stop genocide and fully deploy but has not been able to do so by December 2010 and will have difficulty in doing so by December 2020. Nevertheless, African leaders are attempting to demonstrate that African states and organizations are making an organized effort to posture for action and will continue to ask the major powers to fill shortfalls in financial and military resources. Over-promising and the failure to fully operationalize the ASF lead one to conclude that the next genocide in Africa will be met with a failure to act with sufficient strength.

In regard to burden shifting, the ASF promise to intervene to stop genocide and the slogan of "African solutions for African problems" were welcomed by the United States and other major powers, which had been struggling to find ways to stop genocide. The ASF complemented the preventive Responsibility to Protect principle and the transitional justice institution, the ICC. The ASF proposal enabled the United States and other major powers to invest energies in working with African organizations and militaries without having to develop the doctrine, rapid reaction forces, and contingency plans to intervene to stop genocide.

Given the importance of stopping genocide, alternatives must be sought for the ASF concept, which lacks the political will and capability to stop genocide. African leaders and organizations should openly admit that Africa will not be fully capable to stop genocide while they call on the major powers to fill the gaps and intervene. The international community should pressure the African Union and African states to give an honest account of ASF progress, and lack thereof, and what steps need to be taken to fill the gaps.

In regard to stopping genocide, the R2P principle and the transitional justice regime, embodied by the ICC, are providing alternatives, though suboptimal, to the use of force. The international community, led by human rights NGOs, needs to continue to pressure the major powers and African states and organizations to establish a compact to stop genocide and other major man-made humanitarian disasters. A stepping stone to such a compact would be a commitment by African states to the R2P principle. ${ }^{35}$ With such a commitment, the ASF and developed country forces would find it easier to work together to overcome sovereignty claims and intervene to stop genocide.

Increased commitment and political will by the United States and other major powers in cooperation with a coalition of the willing, including NGOs such as ENOUGH, ${ }^{36}$ could contribute to stopping genocide. The United States and other major powers could provide rapid reaction and air power capabilities and logistics in cooperation with African forces to stop genocide. An example was in Liberia in 2003, when a highly capable force-the 26th US Marine Expeditionary Unit 
(MEU)—combined with a highly salient force-the Nigerian-led ECOWAS Military Mission to Liberia (ECOMIL) - to stabilize a volatile situation, where a cease-fire agreement could have collapsed. Nigerian and ECOWAS desire to end the tyrannical rule of Charles Taylor and US action led to the end of a dangerous stalemate in 2003. ${ }^{37}$ The Liberian case demonstrates that salience is important; if deployment is within the subregion, high salience will motivate the ASF brigades to respond more effectively than if deployed outside of the subregion. If regional military cooperation develops and flourishes, as perhaps in the case of ECOWAS and the West African standby brigade (ECOBRIG), subregional capability to deal with some of the more challenging scenarios requiring enforcement will be enhanced.

A larger question pertains to how African militaries should be organized and led in peace and stability operations. Given the scarcity of resources and dependence on donors and likelihood of more internal conflict in weak African states, the ASF and the subregional commands are not sustainable and will not be for a very considerable period to come. Donor fatigue will eventually pose problems for the ASF. The ASF represents a diversion of scarce resources and time that Africa and its militaries could invest in alternative methods for enhancing African security. The ASF may make African militaries more communicative with each other, but it will not make them dramatically more capable operationally. The lack of logistics, airlift, and training prevents operational progress. Also, it is easier to maintain national units rather than a multinational force with elaborate and difficult command as well as control and planning mechanisms.

Resources being spent on ASF subregional brigades and the AU Peace and Security Commission could be used to better effect to develop the capability of the armed forces of individual states to serve in UN peacekeeping missions. A greater number of highly effective national battalions and brigades could be developed that could be deployed, supported, and commanded by a UN force commander and staff. Most UN operations have a proven record of the sustainment and resolution of many African conflicts, followed by peacebuilding. The UN has resources based on the financial contributions of developed member states and combine developed countries' military resources with developing countries' troops. A related option would be to train the battalions of the most effective African militaries, such as Rwanda's, which would ensure the deployment of more capable African brigades. ${ }^{38}$

Ultimately, priority should be placed on effectiveness, with dependence on the UN and the West, rather than suboptimal security with self-reliance through the ASF concept. The ASF should remain a long-term goal; it could be fully operational by 2020 or 2030 . Under this more modest proposal, African peacekeepers would continue to be deployed with the authorization of the AU or subregional organizations before being taken over by the UN. The UN would continue to assume control over the operations and provide financing, logistics, and other resources.

\section{Notes}

1. The views expressed herein are those of the author and not necessarily those of the US Air War College or the Department of Defense.

2. Stephen D. Krasner, International Regimes (Ithaca: Cornell University Press, 1983), 1; Robert O. Keohane, After Hegemony: Cooperation and Discord in the World Political Economy (Princeton, NJ: Princeton University Press, 1984), 7.

3. Charles P. Kindleberger, "International Public Goods without International Government," The American Economic Review 76, no. 1 (1986): 1-13; Charles Lipson, "International Cooperation in Economic and Security Affairs," World Politics 37, no. 1 (1984): $1-23$. 
4. John Mearsheimer, "Lying in International Politics" (paper presented at the Annual Meeting of the American Political Science Association, 22 August 2004), http://www.allacademic.com//meta/p_mla_apa_research_citation/0/5/9/9/9/pages59994/ p59994-1.php (accessed 3 March 2011).

5. Percy S. Mistry, "Africa's Record of Regional Co-operation and Integration," African Affairs 91, no. 397 (2000): 533-52; Keith Gottschalk and Siegmar Schmidt, "The African Union and the New Partnership for Africa's Development: Strong Institutions for Weak States?" Internationale Politik und Gesellschaft 4 (2004): 138-59; Paul-Henri Bischoff, "Pan-African Multilateralism: Transformative or Disconnected?" Politikon: South African Journal of Political Studies 35, no. 2 (2008): 177-95; James D. Fearon and David D. Laitin, "Neotrusteeship and the Problem of Weak States," International Security 28, no. 4 (2004): 17-18.

6. Convention on the Prevention and Punishment of the Crime of Genocide, 9 December 1948, 78 U.N.T.S. 277, Article I, http://www.preventgenocide.org/law/convention/text.htm (accessed 1 February 2011). There are more than 130 contracting parties including the United States. Article I states, "The Contracting Parties confirm that genocide, whether committed in time of peace or in time of war, is a crime under international law which they undertake to prevent and to punish."

7. "Policy Framework for the Establishment of the African Standby Force and the Military Staff Committee," Part I (document adopted by the Third Meeting of the African Chiefs of Defense Staff, 15-16 May 2003), 3, 6, 7, http://www.africa-union.org/root/au/AUC/ Departments/PSC/Asf/Documents.htm (accessed 3 February 2010); emphasis added.

8. Thabo Mbeki, "The African Renaissance, South Africa and the World" (speech, United Nations University, Tokyo, Japan, 9 April 1998), http://emeagwali.com/speeches/ Thabo-Mbeki/African-Renaissance.html (accessed 3 March 2011).

9. The advocacy group, ENOUGH, was founded with the express purpose of pressuring the US government and other entities to muster the political will and develop the diplomatic instruments to prevent genocide, protect civilians, and punish perpetrators. ENOUGH: The Project to End Genocide and Crimes against Humanity,

http://www.enoughproject.org/ (accessed 1 February 2011).

10. Convention on the Prevention and Punishment of the Crime of Genocide, Article II; emphasis added.

11. Evidence does exist of African intervention at the invitation of sovereign rulers, which has coincidentally stopped massive human rights abuses. In the case of Liberia in 1990, Nigeria and other West African (ECOWAS) states entered the country under the pretense of keeping the peace for an agreement between the regime of President Samuel Doe, who had extended an invitation to intervene to save his regime and stop mass killings, and the rebels led by Charles Taylor. When the peace agreement collapsed, Nigeria insisted on continuing with the intervention as a peace enforcement mission, which coincided with the interests that Nigeria's military dictator, General Ibrahim Babangida, had developed in Liberia.

12. Robert H. Jackson, Quasi-States: Sovereignty, International Relations and the Third World (Cambridge, UK: Cambridge University Press, 1990), 13-31; Christopher Clapham, Africa and the International System: The Politics of State Survival (Cambridge, UK: Cambridge University Press, 2002), 3-27.

13. The government of Rwanda asserts that genocide was committed against the Tutsi minority in 1959, 1973, and 1979 and that persecution continued throughout the 1960s. Government of Rwanda, http://www.gov.rw/Genocide (accessed 3 March 2011).

14. "Decision on the Meeting of African States Parties to the Rome Statute of the International Criminal Court (ICC)," Doc. Assembly AU/13(XIII) (adopted by the Thirteenth Ordinary Session of the Assembly of Heads of State and Government in Sirte, Great Socialist People's Libyan Arab Jamahiriya, 3 July 2009). Evidently, some African leaders feared that they too eventually might be targeted by the ICC. 
15. Alex J. Bellamy, "Realizing the Responsibility to Protect," International Studies Perspectives 10, no. 2, (2009): 111-28; Alex J. Bellamy, The Responsibility to Protect: The Global Effort to Stop Mass Atrocities (Cambridge, UK: Polity Press, 2009).

16. Jeffrey E. Marshall, "Building an Effective African Standby Force to Promote African Stability, Conflict Resolution and Prosperity" (crisis states discussion paper 16, London School of Economics, Development Studies Institute, 2009), 1-31.

17. Alan Kuperman, The Limits of Humanitarian Intervention (Baltimore: Johns Hopkins University Press, 2002), 52-77.

18. On a positive note, the development of early warning mechanisms may mean that Rapid Development Capabilities (RDC) will not have to be in a high state of readiness for prolonged periods and might be able to react within 14 days.

19. Interview with a European Union official, Addis Ababa, Ethiopia, 29 May 2007. The AU mission in Darfur, which the European Union heavily assisted, led EU officials to become disenchanted with the AU and led some to question the value of contributing to the AU Peace Facility.

All interviews were conducted in confidentiality, and the names of interviewees are withheld by mutual agreement.

20. Blair A. Ross Jr., “The U.S. Joint Task Force Experience in Liberia,” Military Review 85, no. 3 (2005): $60-67$.

21. Interview with EU official, May 2007. It is unfortunate that another Rwandan or Darfur genocide may be required to regenerate donor interest.

22. David Dickens, "Can East Timor Be a Blueprint for Burden Sharing?" The Washington Quarterly 25, no. 3 (2002): 29-40.

23. NATO countries took more than three years to respond to genocide ("ethnic cleansing") in Bosnia and were unwilling to commit ground forces to stop the same in Kosovo in 1999.

24. Kristina Bentley and Roger Southall, An African Peace Process: Mandela, South Africa and Burundi (Pretoria, South Africa: Human Sciences Research Council Press, 2005).

25. Mbeki, "The African Renaissance, South Africa and the World."

26. Chris Fomunyoh, "African Solutions for African Problems: A Slogan Whose Time Has Passed," AllAfrica.com, http://allafrica.com/stories/200502090005.html (accessed 9 February 2005).

27. Meetings with Jakkie Cilliers and other security experts, Institute of Security Studies (ISS), Pretoria, South Africa, in March 2003, March 2004, and August 2005. Jakkie Cilliers and other security experts at ISS played a leading role in assisting the South African government to draft the African Union Peace and Security Council and Peace and Security Commission concept papers as well as the African Standby Force concept paper. In so doing, Cilliers and his ISS colleagues were helping to execute the vision of Thabo Mbeki and other South African leaders in drafting the ASF concept, including rapid deployment to stop genocide.

28. While South African leadership was responsible for the ASF concept and its approval, South Africa did not respond militarily to stop genocide in Darfur in 2004. This failure was partly a realization that South Africa did not have the capacity and capability to do so.

29. France is the exception to the rule, as it has demonstrated the willingness to intervene and enforce peace when it launched Operation Licorne in 2002 in Côte d'Ivoire and Operation Artemis in 2003 in the eastern DRC.

30. The Mass Atrocity Response Operation (MARO) Project is a positive sign of efforts to influence the Department of Defense to develop doctrine which would enable the US military, including AFRICOM, to respond to genocide. The project "seeks to enable the United States and the international community to stop genocide and mass atrocity as part of a broader integrated strategy by explaining key relevant military concepts and planning considerations. The MARO Project is based on the insight that the failure to act in the face of mass killings of civilians is not simply a function of political will or legal 
authority; the failure also reflects a lack of thinking about how military forces might respond. States and regional and international organizations must better understand and prepare for the unique operational and moral challenges that military forces would face in a MARO." MARO, http://www.hks.harvard.edu/cchrp/maro/index.php (accessed 3 March 2011).

31. An example of "middle power idealism" occurred when Secretary-General Boutros BoutrosGhali proposed a UN standby force in 1995. The United States and other major powers rejected it, while The Netherlands led other middle powers in supporting the proposal.

32. South African idealism is similar in many respects to Wilsonian idealism.

33. Carl Levan, "The Political Economy of African Responses to the U.S. Africa Command," Africa Today 57, no. 1 (2010): 2-23. Levan finds that the more aid-dependent countries welcomed AFRICOM, while the less aid-dependent countries tended to reject it.

34. Fomunyoh, "African Solutions for African Problems."

35. Bellamy, "Realizing the Responsibility to Protect."

36. ENOUGH, http://www.enoughproject.org/.

37. Ross Jr., "The U.S. Joint Task Force Experience in Liberia," 60-67.

38. However, more trained Rwandan battalions could skew the balance of power in East and Central Africa and could harm civil-military relations inside Rwanda. 